\title{
MORPHOLOGICAL ASSESSMENT OF THE ROOTS, STEMS AND LEAVES OF SOLANUM NIGRUM L. CULTIVATED ON DIFFERENT SOIL TYPES
}

\author{
Ogundola, A. F. - Bvenura, C. - Afolayan, A. J. \\ Medicinal Plants and Economic Development (MPED) Research Centre, University of Fort \\ Hare, P Bag X1314, Alice, 5700, South Africa \\ (afpogundola@gmail.com,tel: +27603447051; cbvenura@ufh.ac.za, tel: +27737241443) \\ *Corresponding author \\ e-mail: aafolayan@ufh.ac.za, fax: +27866282295,tel: +2782202167 \\ (Received $31^{\text {st }}$ Oct 2016; accepted $28^{\text {th }}$ Jan 2017)
}

\begin{abstract}
Solanum nigrum is a wild vegetable well-known for its nutraceutical properties. This plant's proper identification is essential not only to plant scientists but to a wide range of users. A pot experiment was therefore conducted to determine the influence of sandy clay loam, silty clay loam, clay loam and loam soils on the morphology of the plant's roots, stems and leaves. Roots, stems and leaves were viewed under the Scanning Electron Microscope while the leaves were further viewed under the Light Microscope. Silty clay loam recorded the highest stomata, guard, and subsidiary cell densities on the abaxial as well as on the adaxial surface. The LM revealed the hypo-amphistomatous and anisocytic type of stomata in S. nigrum. The SEM analysis revealed the presence of different types of glandular and nonglandular trichromes on both surfaces of the leaves regardless of the soil types. The soil types did not have a significant effect on the root and stem characteristics, however, the stomata, guard and subsidiary cells were significantly affected by the soil types. The presence of trichomes is a good indicator of the ability of S. nigrum to secrete bioactive compounds for which this plant is well known.
\end{abstract}

Keywords: scanning electron microscopy, light microscopy, stomata, trichomes, adaxial and abaxial surfaces

\section{Introduction}

Solanum nigrum belongs to the most complex and largest genus of the Solanaceae family. Furthermore, it comprises over 2000 identical species and this often causes confusion in their taxonomy (Edmond and Chweya, 1997; Bohs, 2001). Most of these species are of great economic and nutritional value and/or importance (Maiti et al., 2002). This plant is one of the African flora known for numerous health benefits (Lester, 2011). Its therapeutic benefits therefore necessitate its proper identification. The responsibility to minimize ambiguity caused by numerous species, overlapping features, ecological distribution, similar genomes and their various growing habitats fall on the researchers (Levin et al., 2005; Oyelana and Ugborogbo, 2008). However, much emphases must be laid on the micromorphology of parts of special interest, especially those that contribute to the plant's therapeutic, nutritional and economic importance. Leaves are some of the most important organs in plants, playing a functional role in addition to containing a number of bioactive compounds (Koduru et al., 2006; Aliero et al., 2006). Leaves contain chlorophyll and stomata which determine the plant's productivity and life. Stomata as leaf components are also associated with many physiological functions in plants. Stomata are responsible for plant biomass accumulation through the process of photosynthesis (Al Afas et al., 2006; Bussis et al., 2006). Like any other plant in the Solanaceae family, S. nigrum stores its bioactive contents in trichomes (Calo et al., 2006). Trichomes are also recognised for storing and 
secreting a higher level of secondary metabolites than quantities produced by other plant tissues (Jakoby et al., 2008). Among other functions, trichomes are also responsible for heat regulation in plants (Wagner et al., 2004). Environmental and hereditary factors are the two major factors that influence stomatal distribution in mature leaves (Fernadez and Muzica, 1973). Various environmental conditions alter density, size, location on the leaf surface and conductivity of stomata (Maherali et al., 2002). These environmental conditions in turn affect biomass production hence the important role of soil types in relation to plant growth. Plant organs such as the stomata, guard and subsidiary cells increase in size and density in response to favourable environmental conditions. This research therefore is interested in those functional parts of plants that determine the growth and yield of the plant. Therefore, stomata, guard cells, subsidiary cells and trichomes; the plant parts which are likely to differ morphologically within the same species will be investigated. Establishing facts on these morphological parts could shed more light into their taxonomy and identification to distinguish different species in the genus Solanum.

Reports indicate that there are differences in seed size and colour, spermodem cell arrangement in the macro-microscopy study of the fruits and powder of different Solanum species (Anuradha et al., 2012). There are reports on plant stomata response to various environmental conditions from molecular level to whole plant perspectives, ecosystems and global level (Nilson and Asmann, 2007; Woolward, 1987). Other reports include changes in stomatal density to elevated carbon-dioxide, salt stress and plant density (Zhao et al., 2006; Zhang et al., 2003). Many studies have also been carried out relating water deficit to an increase in stomatal density, size and adaptive nature of the specific plant to moisture stress (Spence et al., 1986; Yang and Wang, 2001; Zhang et al., 2006). However, no study has been conducted to examine the influence of soil types on root, stem and leaf morphology of S. nigrum. Earlier studies indicate that warmth stimulates and assists African indigenous vegetables to exhibit their potentials including S. nigrum (Flyman and Afolayan, 2006). The response of $S$. nigrum cultivated on a particular soil type calls for morphological assessment due to differences in water and nutrient retention capacities of different soil types. Distribution, density, size and type of stomata and the magnitude of the adaptation mechanism exhibited by stomata in response to different soil types are of major interest. The present study therefore aimed to morphologically identify $S$. nigrum stems, roots, trichomes and stomata cultivated on different soil types. The types of trichomes acquired by the plant are expected to be elucidated using energy dispersing $\mathrm{X}$ - ray microscopy and light microscopy. Information leading to the proper identification of S. nigrum from other species of the genus Solanum is expected to be gleaned from this study.

\section{Materials and methods}

\section{Soil collection, treatments and study area}

The soil was collected from a fallow land at a depth of $30 \mathrm{~cm}$ from the University of Fort Hare farm, Alice campus in South Africa located at $32^{\circ} 46^{\prime} 47^{\prime}$ 'S and $26^{\circ} 50^{\prime} 5^{\prime \prime}$ 'E and $524 \mathrm{~m}$ a.s.l. Soil treatments were relative combinations of sand, silt and clay in different proportions. The physico-chemical properties of soil types are shown in Table 1. 
Table 1. Textural compositions of experimental soils

\begin{tabular}{l|ccc}
\hline Soil types & Sand particle $\%$ & Silt particles \% & Clay particles\% \\
\hline Control $\mathrm{ST}_{0}$ & 60 & 30 & 10 \\
Sandy clay loam ST & 66 & 13 & 21 \\
Silty clay loam $\mathrm{ST}_{2}$ & 10 & 60 & 30 \\
Clay loam $\mathrm{ST}_{3}$ & 36 & 30 & 34 \\
${\text { Loam } \mathrm{ST}_{4}}$ & 40 & 40 & 20 \\
\hline
\end{tabular}

\section{Plant materials}

Seeds were extracted from mature berries of plants by hand squeezing, washing in distilled water and air-drying for 3 days and planted in nursery trays in the green house. Seedlings of $S$. nigrum were transplanted at 4 leaf stage into experimental pots containing different textural soil compositions (Table 1). The trial was conducted between February and March, 2016 at the University of Fort Hare, Alice campus, Eastern Cape, South Africa, located at 32 $46^{\prime} 47^{\prime}$ 'S and 2650' 5' 'E and 524m a.s.l. The plant had earlier been identified (BVE11/017) and deposited at the Giffen herbarium of the same University (Bvenura and Afolayan, 2013). For the micromorphological study of $S$. nigrum root and stem specimens cultivated on different soil types were harvested at the plant's early flowering stage ( $4^{\text {th }}$ week). The first pair of mature, fresh and fully expanded leaves were collected and specimens measuring $10 \times 10 \mathrm{~mm}^{2}$ cut for SEM analysis.

\section{SEM and Energy Dispersive X-ray Spectroscopy (SEM-EDX)}

Following the procedure adopted from Dyubeni and Buwa (2012) the specimens (root, stem and leaves) of sizes 4, 6 and $10 \mathrm{~mm}$ respectively were immersed in $6 \% \mathrm{w} / \mathrm{v}$ glutaraldehyde in $0.05 \mathrm{M}$ sodium cacodylate buffer ( $\mathrm{pH} 7.5$ ) for 24 hours. The samples were then rinsed with distilled water and dehydrated in different graded ethanol series of $20-100 \%$ at 20 minutes per rinse. Specimens were then immersed in $100 \%$ ethanol solvent till the time of drying. Samples were prepared for drying by mounting on aluminium specimen stubs with a double-sided carbon tape and sputter coated with a layer of gold. Samples were critical point dried using liquid $\mathrm{CO}_{2}$ in a Hitachi HCP- 2 critical point drier, and sputter coated with gold palladium in a Hummer V-sputter coater. Both the adaxial and abaxial surfaces were observed in a Hitachi (S-450) Scanning Electron Microscope (SEM), operating at 10-15 KV acceleration voltage. Images were captured digitally with an image slave computer programme for windows.

\section{Light microscopy}

For better leaf micromorphological assessment of stomata and the companion cells, freshly harvested leaves of plants from different soil types were prepared for observation under the light microscope. A strip of lower and upper epidermis from the middle portion of the leaves were carefully peeled off to show the transparent part (Marenco et al., 2009; Coopoosamy and Naidoo, 2011). Images were viewed with a Zeiss West Germany optical microscope digital camera (DCM 510) at 100X and 400X magnification. An image showing the number, arrangement of stomata with guard cells 
and subsidiary cells was captured with the digital camera, fitted in the light microscope. The images were captured digitally using Microsoft image programme for Windows.

\section{Effect of soil types on density and size of stomata, guard cells, and subsidiary cells}

Leaf stomatal density was determined and expressed as the number of stomata per unit area (Radoglou and Jarvis, 1990). This was achieved by counting the number of full or half shown stomata within a $50 \mu \mathrm{m}$ unit area at $500 \mathrm{X}$ magnification on the lower and upper surfaces of the specimens analysed by the SEM. Density of stomata per $\mathrm{mm}^{2}$ was calculated and recorded for each soil type. The density of guard cells and subsidiary cells was determined as each of two double the density of the stomata since they both occur in pairs, surrounding the stomata. The size of each of these parameters is determined by length, therefore, 3 stomata cells, were selected and the mean value represents the size.

\section{Effect of soil types on distribution and types of stomata}

Using the concept of Silva et al. (2008), assessment was made based on the number, type of arrangement and position of accessory cells surrounding the guard cells of the stomata. Critical observations were made on the lower and upper surfaces of leaf specimens from the SEM and light microscopy analysis for possible changes in relation to soil types.

\section{Effect of soil types on roots and stems}

$S$. nigrum roots and stems were observed for possible changes in their micromorphology under the SEM following the method of Otang et al. (2012).

\section{Effect of soil types on distribution and types of trichome}

Across the soil types, both lower and upper surfaces of leaf specimens of S. nigrum were observed for distribution and types of trichomes present in them under the SEM and light microscope following the method of Otang et al. (2012).

\section{Statistical analysis}

All data on density and size were subjected to statistical analysis using MINITAB Release 17. A one-way analysis of variance (ANOVA) was used to compare the mean values among the soil treatments. Means were segregated using Fisher's Least Significant Difference (LSD) paired wise comparison. The means were treated as significantly different at $\mathrm{p}<0.05$.

\section{Results and discussions}

Soil types used for the growth of $S$. nigrum in this study were composed of different sand, silt and clay proportions as shown in Table 1.

\section{Effect of soil types on density and size of stomata, guard cells, and subsidiary cells}

Based on the results of the SEM analysis, stomata density, guard cell and subsidiary cell density were influenced by soil types in both lower and upper surfaces of the leaves. 
As shown in Table 2, the density of stomata, guard and subsidiary cell on the adaxial surface decreased in the order: $\mathrm{ST}_{2}>\mathrm{ST}_{3}>\mathrm{ST}_{4}>\mathrm{ST}_{1}>\mathrm{ST}_{0}$. In addition, on the abaxial surface these constituents decreased in the order: $\mathrm{ST}_{2}>\mathrm{ST}_{3}>\mathrm{ST}_{1}>\left(\mathrm{ST}_{4}=\mathrm{ST}_{0}\right)$. The present results indicate that stomata density, guard cell and subsidiary cell densities declined as the sand ratio increased. Highest stomata, guard and subsidiary cell densities on the lower surface (287.8, 575.6 and 575.6) and on the upper surface (205.6, 411.2 and 411.2) were recorded in samples cultivated on silty clay loam soil. The control soil recorded the lowest stomata density, guard cell and subsidiary cell densities $(164.5,329$ and 329) on the lower surface and sandy clay loam soils recorded the lowest stomata density, guard cell and subsidiary cell densities (61.7, 123.4 and 123.4) on the upper surfaces as shown in Table 2. Silty clay loam soil had the highest stomata density per $\mathrm{mm}^{2}$ in both lower and upper leaf surfaces. Silty clay loam soil recorded significantly increased density of stomata, guard cell and subsidiary cells when compared with the control. However, the average shortest distance between stomata $(21.7 \mathrm{~mm})$ was recorded in silty clay loam on the lower leaf surface. The longest distance $(46.7 \mathrm{~mm})$ was recorded in control soils on the upper surface (Table 2). Higher densities of stomata, guard and subsidiary cells recorded in silty clay loam, clay loam and loam soils could be as a result of the ability of these soils to retain water and nutrients as compared to other soils with higher sand proportions which is characterised by larger pores that drain water and leach nutrients (Soil Conservation Service Engineering Division, 1964; Bengough et al., 2011). The ability of silty clay loam soil to retain water for plant uptake in comparison with other soil types could possibly explain the increased stomata, guard and subsidiary cell densities in the plants grown on this soil. This could also be responsible for increased biomass accumulation (Marenco et al., 2006). Regardless of the soil types, stomata were more distributed on the adaxial than on the abaxial surfaces. This is a general phenomenon with angiosperms (Metcalfe and Chalk, 1979; Volekonifa and Ticha, 2001). Moreover, it is a characteristic of hypo-amphistomatous leaves, of which $S$. nigrum is a member (Volenikova and Ticha, 2001). This high mean stomata density recorded in silty clay loam soil in addition to the high mean sizes of the stomata could possibly explain the high growth and yield potentials exhibited by S. nigrum cultivated on these soils. However, in general, there is an inverse relationship between stomatal density and stomatal size which is in contrast with the results of the current experiment (Marenco et al., 2006). The present results differed from those of Zhang et al. (2004) which affirmed an inverse relationship between stomatal size and density. Moreover, the effects of any abiotic factors on stomatal size have been reported to be dependent on plant species or varieties (Maherali et al., 2002).

\section{Effect of soil types on distribution and types of stomata}

The arrangement of the stomata on adaxial and abaxial leaf surfaces of $S$. nigrum are shown in Fig 1. Two large and one small subsidiary/ accessory cells with their common walls parallel to the guard cells surrounded the stomata as described by Metacalf and Chalk, (1979). The five soil types did not significantly affect $(\mathrm{p}<0.05)$ stomatal, guard as well as subsidiary cell characteristics throughout the trial. Also, the stomata arrangement was anisocytic as described by Silva et al. (2008). 
Table 2. Effect of soil types on stomata, guard and subsidiary cell characteristics

\begin{tabular}{|c|c|c|c|c|c|c|c|c|c|c|}
\hline Leaf indices & \multicolumn{5}{|c|}{ Upper surface } & \multicolumn{5}{|c|}{ Lower surface } \\
\hline Soil types & $\mathrm{ST}_{0}$ & $\mathrm{ST}_{1}$ & $\mathrm{ST}_{2}$ & $\mathrm{ST}_{3}$ & $\mathrm{ST}_{4}$ & $\mathrm{ST}_{0}$ & $\mathrm{ST}_{1}$ & $\mathrm{ST}_{2}$ & $\mathrm{ST}_{3}$ & $\mathrm{ST}_{4}$ \\
\hline Stomatal density $\mathrm{mm}^{-2}$ & $61.7 \pm 0.0^{\mathrm{d}}$ & $82.3 \pm 1.0^{\mathrm{c}}$ & $205.6 \pm 0.2^{\mathrm{a}}$ & $102.8 \pm 0.1^{\mathrm{b}}$ & $61.7 \pm 0.0^{\mathrm{d}}$ & $164.5 \pm 1.0^{\mathrm{e}}$ & $185 \pm 1.00^{\mathrm{d}}$ & $287.8 \pm 1.0^{\mathrm{a}}$ & $267.3 \pm 0.2^{b}$ & $246.7 \pm 0.6^{\mathrm{c}}$ \\
\hline Stomatal length $\mathrm{mm}$ & $8.2 \pm 0.7^{\mathrm{b}}$ & $9.0 \pm 1.0^{\mathrm{b}}$ & $13.6 \pm 1.0^{\mathrm{a}}$ & $10.0 \pm 2.4^{\mathrm{b}}$ & $9.0 \pm 1.9^{\mathrm{b}}$ & $7.3 \pm 0.7^{\mathrm{c}}$ & $8.3 \pm 0.1^{\mathrm{ab}}$ & $9.3 \pm 0.7^{\mathrm{a}}$ & $9.0 \pm 1.0^{\mathrm{a}}$ & $9.0 \pm 1.7^{\mathrm{a}}$ \\
\hline Guard cell density $\mathrm{mm}^{-2}$ & $123.4 \pm 1.0^{\mathrm{e}}$ & $164.6 \pm 0.6^{\mathrm{d}}$ & $411.2 \pm 1.0^{\mathrm{a}}$ & $205.6 \pm 1.0^{\mathrm{b}}$ & $123.4 \pm 0.9^{\mathrm{c}}$ & $329.0 \pm 1.0^{\mathrm{a}}$ & $370 \pm 0.6^{d}$ & $575.6 \pm 1.0^{\mathrm{a}}$ & $534.6 \pm 1.0^{\mathrm{b}}$ & $493.4 \pm 0.9^{\mathrm{d}}$ \\
\hline Guard cell length mm & $8.4 \pm 0.4^{\mathrm{c}}$ & $9.3 \pm 1.0^{\mathrm{bc}}$ & $14.0 \pm 0.7^{\mathrm{a}}$ & $11.0 \pm 1.4^{\mathrm{b}}$ & $13.0 \pm 1.2^{\mathrm{a}}$ & $8.0 \pm 1.0^{\mathrm{c}}$ & $13.5 \pm 1.0^{\mathrm{a}}$ & $11.3 \pm 0.3^{\mathrm{a}}$ & $10.7 \pm 0.2^{\mathrm{b}}$ & $12.0 \pm 1.0^{\mathrm{a}}$ \\
\hline Subsidiary cell densitymm ${ }^{-2}$ & $123.4 \pm 0.7^{\mathrm{c}}$ & $164.6 \pm 0.1^{\mathrm{bc}}$ & $411.2 \pm 0.7^{\mathrm{a}}$ & $205.6 \pm 1.0^{\mathrm{b}}$ & $123.4 \pm 1.7^{\mathrm{a}}$ & $329.0 \pm 1.0^{\mathrm{e}}$ & $370 \pm 0.6^{\mathrm{d}}$ & $575.6 \pm 1.0^{\mathrm{a}}$ & $534.6 \pm 1.0^{\mathrm{b}}$ & $493.4 \pm 0.9^{\mathrm{d}}$ \\
\hline Subsidiary cell length mm & $12.0 \pm 1.0^{\mathrm{c}}$ & $13.5 \pm 0.1^{\mathrm{b}}$ & $16.0 \pm 0.2^{\mathrm{a}}$ & $12.6 \pm 0.1^{\mathrm{b}}$ & $13.0 \pm 1.0^{\mathrm{a}}$ & $9.7 \pm 1.7^{\mathrm{b}}$ & $9.3 \pm 1.3^{\mathrm{b}}$ & $12.3 \pm 0.3^{\mathrm{a}}$ & $12.0 \pm 0.0^{\mathrm{a}}$ & $13.3 \pm 0.3^{\mathrm{a}}$ \\
\hline Distance between stomata $\mathrm{mm}^{2}$ & $46.7 \pm 0.8^{\mathrm{a}}$ & $36.3 \pm 1.0^{\mathrm{b}}$ & $25.0 \pm 0.2^{\mathrm{c}}$ & $26.0 \pm 0.3^{\mathrm{c}}$ & $45.0 \pm 2.0^{\mathrm{a}}$ & $23.5 \pm 0.5^{\mathrm{c}}$ & $31 \pm 1.4^{\mathrm{a}}$ & $21.7 \pm 1.0^{\mathrm{d}}$ & $23.7 \pm 0.1^{\mathrm{c}}$ & $26.0 \pm 1.0^{\mathrm{b}}$ \\
\hline
\end{tabular}



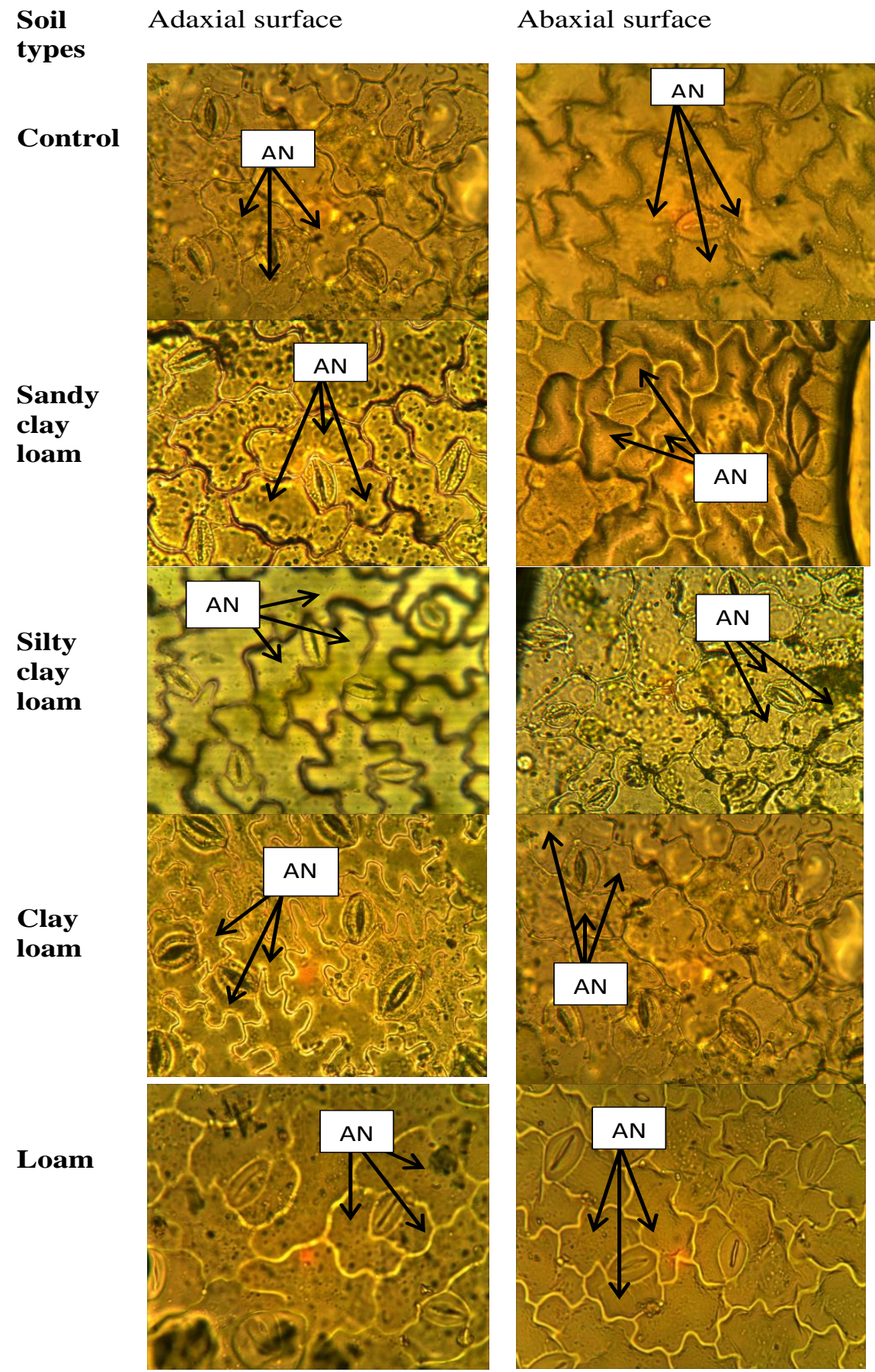

Figure 1. Stomata distribution on Solanum nigrum leaves showing Anisocytic (AN) stomata surrounded by 2 large and 1 small accessory cells

\section{Effect of soil types on roots and stems of $S$. nigrum}

The effects of soil type on root and stem characteristics of S. nigrum are shown in Fig. 2. The results indicate that the soil types did not significantly affect the root and stem characteristics except for minor variations in the sizes of the xylem. 

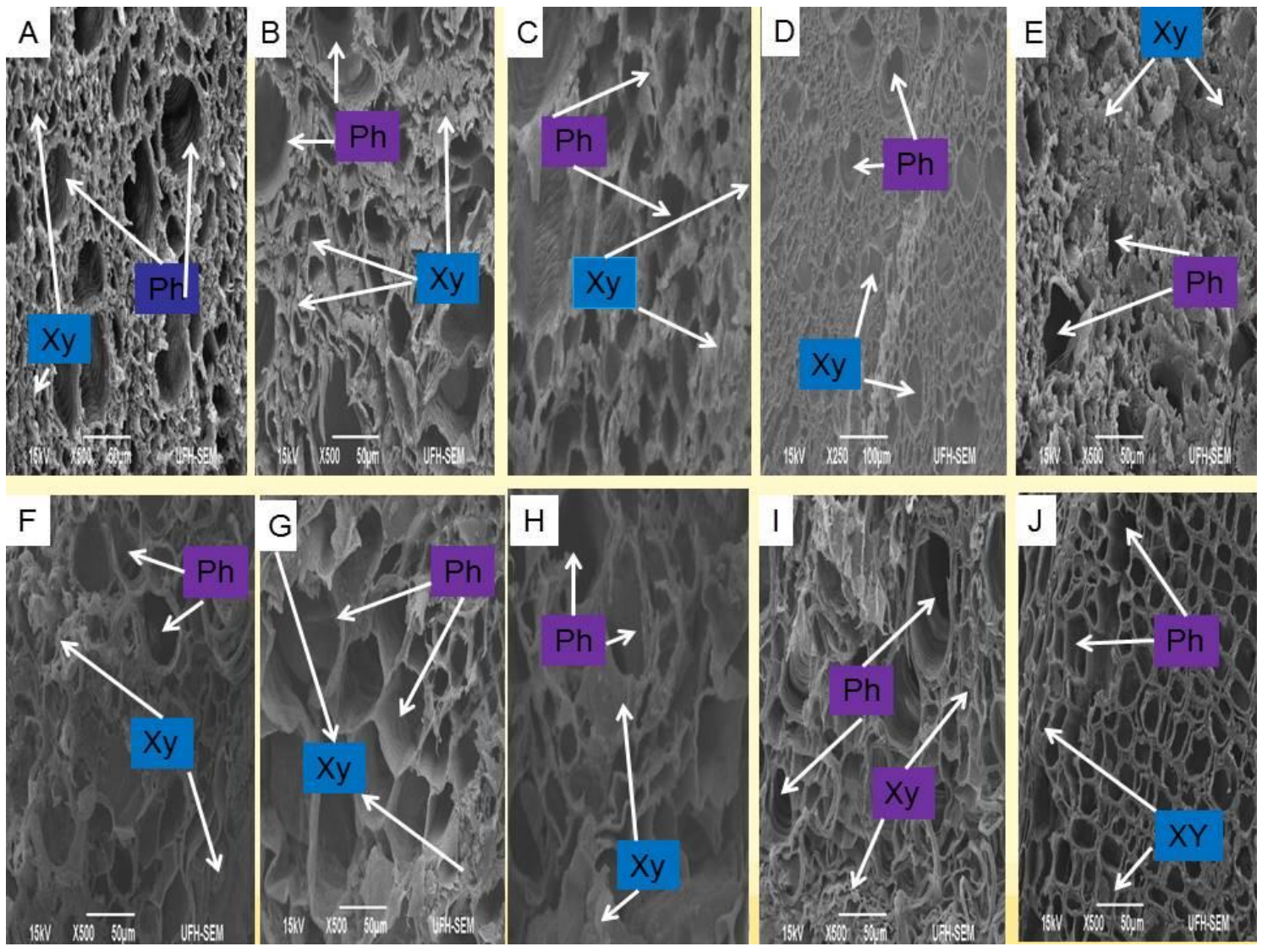

Figure 2. Effect of soil types on roots and stems of S. nigrum. $P h=$ Phloem, $X y=X y l e m$

The xylem vessels in the roots of silty clay loam, clay loam and loam soil cultivated plants appeared more compacted as compared to the control and sandy clay loam soils. The basic function of xylem is to transport water while phloem transports photosynthate and nutrients.

\section{Effect of soil types on distribution and types of trichomes}

Distribution of trichomes was not significantly affected by the soil types as shown in Fig. 3a. Trichomes were found on both adaxial and abaxial surfaces in the foliage of $S$. nigrum as it occurs in some other dicotyledonous leaves. These vary from glandular to non-glandular with arrow/sharp end, knob-like head and point end Figure $3 a$. The two types of trichomes (glandular and non-glandular) were simultaneously found on both adaxial and abaxial surfaces of leaves Figure $3 b$. It was also observed that these trichomes were multicellular but they exist in solitary form.

SEM analysis showed the occurrence of glandular trichomes on both leaf surfaces. The abundance of trichomes in a plant is generally linked to increased secretion of bioactive compounds, the therapeutic substances responsible for the plant's economic importance (Maiti et al., 2002). The abundance of trichomes in the present study is therefore an indicator of the high therapeutic disposition of $S$. nigrum and therefore a good source of secondary compounds (Afolayan and Meyer, 1995; Ascensao et al., 1999; Calo et al., 2006). The possession of glandular trichomes is a characteristic of the 
genus Solanum with the exception of Nicotiana glauca and Solandra nitida (Maiti et al., 2002). The solitary form of existence of all the present trichomes is deviant from the type of trichomes reported in Solanum aculeastrum, which were multicellular but some exist in stellate form (Koduru et al., 2006).

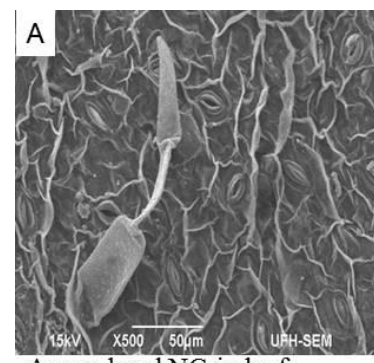

Arrow head NG in leaf grown on clay loam soil

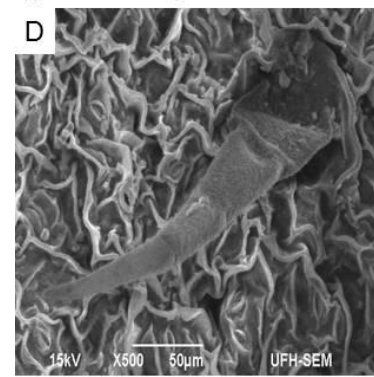

Sharp head NG in leaf grown on sandy clav loam
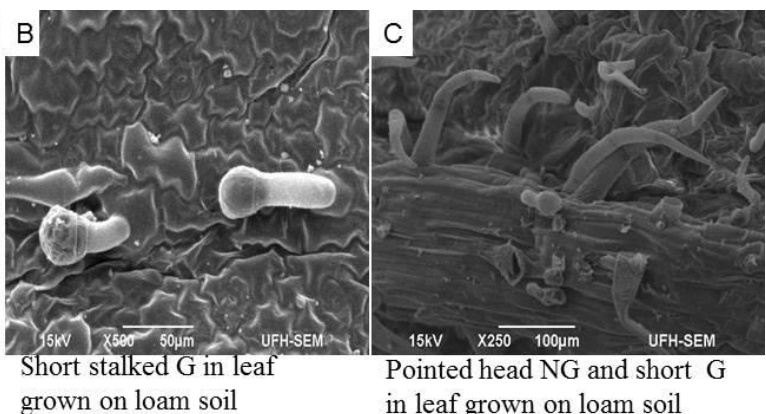

Pointed head NG and short $G$ in leaf grown on loam soil

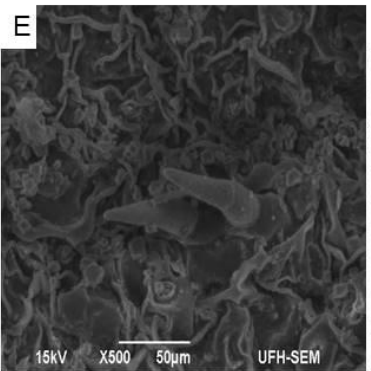

Point head NG in leaf grown on control soil

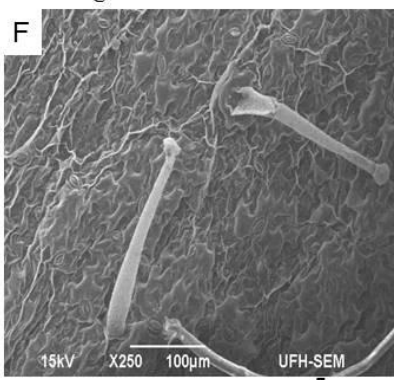

Knob head long stalked $\mathrm{G}$ in leaf grown on control soil

Figure 3.1. Effect of soil types on distribution and types of trichome. $N G=$ non glandular trichome; $G=$ glandular trichome

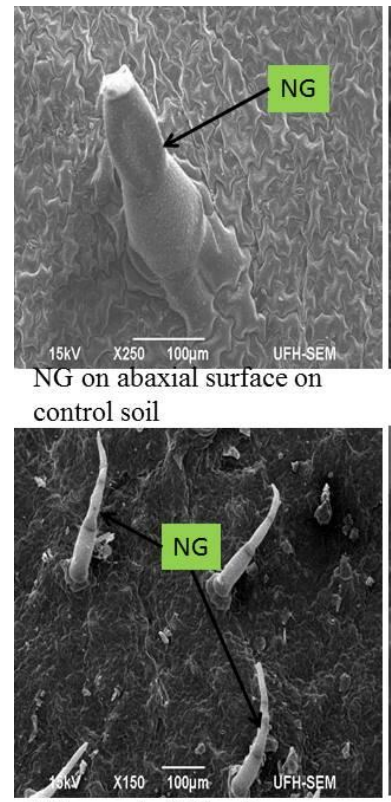

NG on adaxial leaf surface on control soil

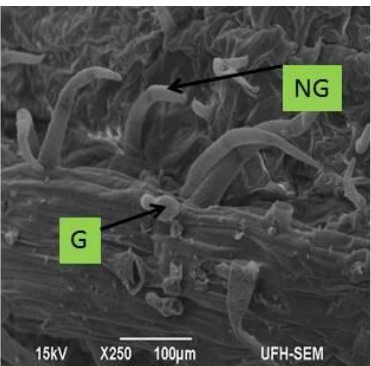

$G$ and NG on abaxial leaf mid vein on loam soil

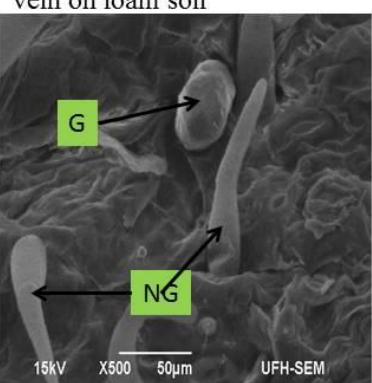

$\mathrm{G}$ and NG on adaxial leaf surface on clav loam soil

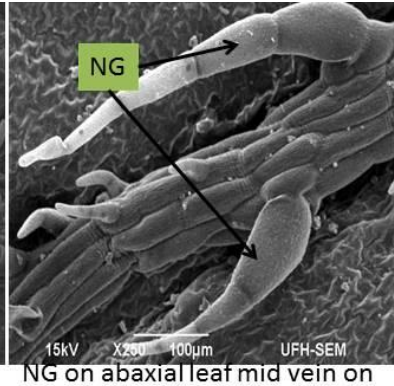

clay loam soil

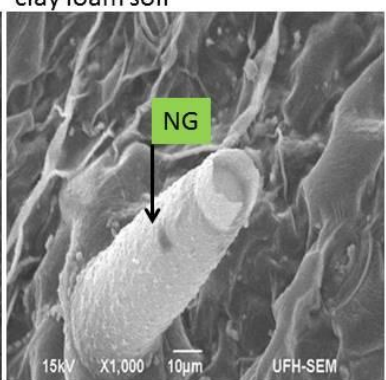

NG on abaxial leaf surface on clav loam soil

Figure 3.2. Effect of soil types on distribution and types of trichome. $N G=$ non glandular trichome; $G=$ glandular trichome 


\section{Conclusion}

Soil types significantly influenced density, size and distribution of stomata as well as guard and subsidiary cells. The results of the present study confirmed that $S$. nigrum leaves possess hypo-amphistomatous and anisocytic stomata. This study also observed the occurrence of glandular and non-glandular trichomes on the leaves, whose heads were either sharp, point or knob-like. The occurrence of glandular and non-glandular trichomes was on both abaxial and adaxial surfaces of the mid-vein of the leaves. The presence of glandular trichomes might be responsible for the therapeutic importance of $S$. nigrum, since glandular trichomes are known for secreting bioactive compounds. However, soil types did not have any influence on root and stem characteristics of $S$. nigrum cultivated on them.

Acknowledgements. This work was supported by National Research Foundation (NRF) of South Africa; Govan Mbeki Research Development Centre of the University, University of Fort Hare, South Africa and Tertiary Education Trust Fund (TETFUND), LAUTECH, Nigeria.

\section{REFERENCES}

[1] Afolayan, A.J., Meyer, J.J.M. (1995): Morphology and ultrastructure of secreting and nonsecreting foliar trichomes of Helichrysum aureonitens (Asteraceae). - International Journal of Plant Science 156: 481-487.

[2] Al Afas, N., Marron, N., Ceulemans, R. (2006): Clonal variation in stomatal characteristics related to biomass production of 12 poplar (Populus) clones in a short rotation coppice culture. - Enviromental and Experimental Botany 58: 279-286.

[3] Aliero, A.A., Grierson, D.S., Afolayan, A.J. (2006): The foliar micromorphology of Solanum pseudocapsicum. - Flora 201: 326-330.

[4] Anuradha, U, Kumbhalkar, B., Deshpande, A. (2012): Macro-microscopic evaluation and HPTLC- densitometric analysis of solasodine from fruits of some medicinally important species in genus Solanum Linn. - Indian Journal of Natural Products Resources 3 (2): 166-172.

[5] Ascensa, O.L., Pais, M.S.S. (1987): Glandular trichomes of Artemisia campestris (ssp. maritima): ontogeny and histochemistry of the secretory product. - Botany Gazette 148:221-227.

[6] Bengough, A.G., McKenzie, B.M., Hallet, P.D., Valentine, T.A. (2011): Root elongation, water stress, and mechanical impedance: a review of limiting stresses and beneficial root tip traits. - Journal of Experimental Botany 62: 59-68.

[7] Bohs, L. (2001): Revision of Solanum Section Cyphomandropsis (Solanaceae). Systematic Botany Monogr 61:185.

[8] Bussis, D., Von Groll, U., Fisahn, J., Altman, T. (2006): Stomatal aperture can compensate altered stomatal density in Arabidopsis thaliana at growth light conditions. Functional Plant Biology 33: 1037-1043.

[9] Bvenura, C., Afolayan, A. J. (2013): Growth and physiological response to organic and/or inorganic fertilisers of wild Solanum nigrum L. cultivated under field conditions in Eastern Cape Province, South Africa. - Acta Agriculturae Scandinavica, Section B - Soil and Plant Science 63 (8): 683-693. http://dx.doi.org/10.1080/09064710.2013.852616

[10] Calo, L. (2006): Leaf hairs influence phytopathogenic fungus infection and confer an increased resistance when expressing a Trichoderma alpha-1, 3-glucanase. - Journal of Experimental Botany 57: 3911-3920. 
[11] Coopoosamy, R.M., Naidoo, K.K. (2011): Anatomical features of the medicinal importanceof Aloe excelsa (Berger). - African Journal of Biotechnology 10 (39):76227632.

[12] Dyubeni, L., Buwa, L.V. (2012): Foliar micromorphology of Salvia greggii A. Gray (Lamiaceae). - African Journal Plant Science 6: 32-38.

[13] Edmonds, J. M., Chweya, J. A. (1997): Blacknightshades: Solanum nigrum L. and related species. Promoting the conservation and use of underutilized and neglected crops 15. International Plant Genetic Reources Institute, Rome.

[14] Fernandez, O. A., Mujica, B. (1973): Effects of some environmental factors on the differentiation of stomata in Spirodela intermedia Koch W. - Botanical Gazette 134(2): 117-121.

[15] Flyman, M.V., Afolayan, A.J. (2006): The suitability of wild vegetables for alleviating human dietary deficiencies. - South African Journal of Botany 72: 492-497.

[16] Jakoby, M.J., Falkenhan, D., Mader, M.T., Brininstool, G., Wischnitzki, E., Platz, N., Hudson, A., Hulskamp, M., Larkin, J., Schnittger, A. (2008): Transcriptional profiling of mature Arabidopsis trichomes reveals that NOECK encodes the MIXTA-like transcriptional regulator MYB106. - Plant Physiology 148: 1583-1602.

[17] Koduru, S., Grierson, D.S., Aderogba, M.A., Eloff, J.N., Afolayan, A.J. (2006): Antioxidant activity of Solanum aculeastrum (Solanaceae) berries. - International Journal of Pharmacology 2: 262-264.

[18] Lester, R.N., Peter-Martin, L.J., Alan, C. (2011): Solanum in Africa. Classification, types and their locations. A PhD thesis. - Birmingham University.

[19] Levi, R.A., Watson, K., Bohs, L. (2005): A Four gene Study of Evolutionary Relationships Solanum Section Acanthophora. - American Journal of Botany 92(4):603 612.

[20] Maherali, H., Reid, C.D., Polley, H.W., Johnson, H.B., Jackson, R.B. (2002): Stomatal acclimation over a sub-ambient to elevated $\mathrm{CO} 2$ gradient in a $\mathrm{C} 3 / \mathrm{C} 4$ grassland. - Plant Cell and Environ. 25: 557-566.

[21] Maiti, R.K., Villarreal, L.R., Trevino, A.V., Valades-Cerda, M.C. (2002): Some aspects on pharmacognosy of ten species of the family solanaceae utilized in traditional medicine. - Caldasia 24: 317-321.

[22] Marenco, R.A., Siebke, K., Farquhar, G.D., Ball, M.C. (2006): Hydraulically based stomatal oscillations and stomatal patchiness in Gossypium hirsutum. -Functional Plant Biology 33:1103-1113.

[23] Metcalfe, C.R., Chalk, L. (1979): Anatomy of the Dicotyledons. Vol. 1. - Clarendon Press, Oxford.

[24] Nilson, S.E., Assmann, SM. (2007): The control of transpiration. Insights from Arabidopsis. - Plant Physiology 143: 19-27.

[25] Otang, W.M., Grierson, D.S., Ndip, R. (2014): Foliar micromorphology of Gasteria bicolor Haw. (Aphosdelaceae) from South Africa. - Afr. J. Traditional Complimentary Alternative Medicine 11(4): 71-76.

[26] Oyelana, O.A., Ugborogho, R.E. (2008): Phenotypic variation of F1 and F2 populations from three species of Solanum L. (Solanaceae). - African Journal of Biotechechnology 7(14): 2359-2367.

[27] Radoglou, K.M, Jarvis, P.G. (1990): Effects of $\mathrm{CO}_{2}$ enrichment on four poplar clones. II. Leaf surface properties. - Annals of Botany 65: 627-632.

[28] Silva, O. Serrano, R. A., Gomes, E.T. (2008): Botanical characterization of Guiera senegalensis leaves. - Microscop Microanal. 14 (5): 398-404.

[29] Soil Conservation Service Engineering Division (1964): Irrigation: Soil-Plant-Water Relationships. - All U.S. Government Documents (Utah Regional Depository). Paper 516. http://digitalcommons.usu.edu/govdocs/516. 
[30] Spence, R.D., Wu, H., Sharpe, P.J.H., Clark, K.G. (1986): Water stress effects on guard cell anatomy and the mechanical advantage of the epidermal cells. - Plant, Cell and Environment 9:197-202.

[31] Voleníková ,M., Tichá, I. (2001): Insertion profiles in stomatal density and sizes in Nicotiana tabacum L. plantlets. - Biologia Plantarum 44: 161-165.

[32] Wagner, G., Wang, E., Shepherd, R. (2004): New approaches for studying and exploiting an old protuberance, the plant trichome. - Annal Botany. (Lond). 93: 3-11.

[33] Woodward, F.I. (1987): Stomatal numbers are sensitive to increases in CO2 from preindustrial levels. - Nature 327: 617-618.

[34] Yang, H.M., Wang, G.X. (2001): Leaf stomatal densities and distribution in Triticum aestivum under drought and CO2 enrichment. - Acta Phytoecologica Sinica 25: 312-316.

[35] Yang, H.M., Wang, G.X. (2001): Leaf stomatal densities and distribution in Triticum aestivum under drought and $\mathrm{CO}_{2}$ enrichment. - Acta Phytoecologica Sinica 25: 312-316.

[36] Zhang, H., Wang, X., Wang, S. (2004): A study on stomatal traits of Platanus acerifolia under urban stress. - Journal of Fudan University 43: 651-656.

[37] Zhang, X.Y., Wang, H.M., Hou, Z.D., Wang, G.X. (2003): Stomatal density and distributions of spring wheat leaves under different planting densities and soil moisture levels. - Acta Phytoecologica Sinica 27: 133-136.

[38] Zhang, Y.P., Wang, Z.M., Wu, Y.C., Zhang, X. (2006): Stomatal characteristics of different green organs in wheat under different irrigation regimes. - Acta Agronomica Sinica 32: 70-75.

[39] Zhao, S., Chen, W., Ma, D., Zhao, F. (2006): Influence of different salt level on stomatal character in rice leaves. - Reclaiming and Rice Cultivation 6: 26-29. 